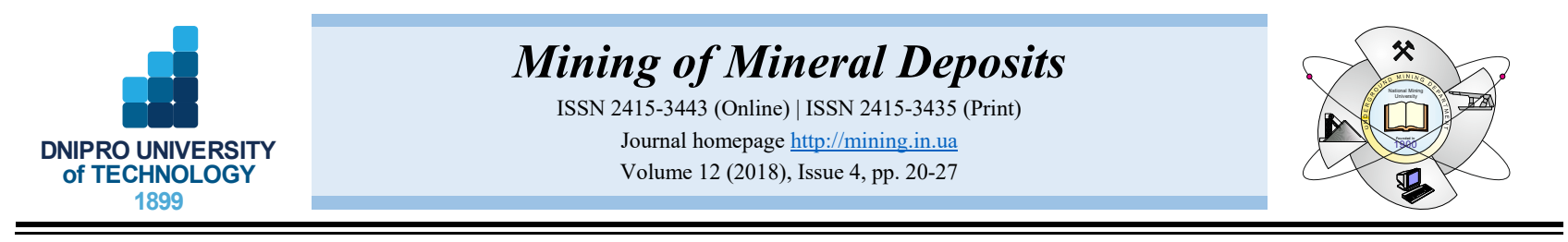

UDC 622.023 .2

https://doi.org/10.15407/mining12.01.020

\title{
EFFECTS OF ELEVATED TEMPERATURE ON PHYSICAL AND MECHANICAL PROPERTIES OF CARBONATE ROCKS IN SOUTH-SOUTHERN NIGERIA
}

\author{
M.A. Idris ${ }^{1 *}$ \\ ${ }^{l}$ Federal University of Technology Akure, Akure, Nigeria \\ *Corresponding author: e-mail maidris@futa.edu.ng, tel. +2347060928848
}

\begin{abstract}
Purpose. Limestone and marble are carbonate rocks with several structural and engineering applications. The physical and mechanical properties of the rocks are fundamental as they determine their suitability for various use. Temperature is one of the critical factors that could affect the properties of the rocks and consequently their engineering application. Therefore, a better understanding of how the temperature, especially when it is higher than ambient, will affect the properties of the rocks is essential. In this work, the effects of the elevated temperature on some physical and mechanical properties of the carbonate rocks have been studied.
\end{abstract}

Methods. Cubic samples of the rocks were prepared and heated in a furnace to different temperatures up to $900^{\circ} \mathrm{C}$ at an interval of $100^{\circ} \mathrm{C}$ and then cooled to the room temperature for testing. Porosity, dry density and uniaxial compressive strength (UCS) of the samples were determined under the effect of the elevated temperature. The porosity and dry density were determined using the saturation and buoyancy method while the UCS was estimated from the point load index tests performed on the samples.

Findings. The results of this work indicate that the elevated temperature has significant effects on the physical and mechanical properties of the rocks. The porosity of the rocks showed an increasing trend as the temperature was increased while the density steadily decreased especially at the temperature above $300^{\circ} \mathrm{C}$. The UCS of the rocks also declines with increased temperature but with an intermittent increase in their strength at a specific heating temperature.

Originality. Most of the available studies on Nigerian carbonate rocks are focused on the estimation of physical and mechanical properties of the rocks without considering changes in these properties when the rocks are subjected to high temperatures. This study therefore aims to fill the gap by investigating the effects of the elevated temperatures on the physical and mechanical properties of some of the Nigerian carbonate rocks.

Practical implications. The results of this study further increase understanding of the effect of high temperature on carbonate rocks, and also help to identify the critical temperature at which the properties of carbonate rocks undergo significant and irreversible changes. This information is very important for restoration of valuable fire-damaged structures made of carbonate rocks.

Keywords: limestone, marble, elevated temperature, rock properties, heat treatment

\section{INTRODUCTION}

Carbonate rocks are a class of sedimentary rocks composed primarily of carbonate minerals. Limestone and dolomite are the major types of carbonates rock while marble is a metamorphic derivative of the carbonate rocks. These types of rock are widely abundant in the upper crust and it covers around 23\% of the earth crust (Shafiei \& Dusseault, 2012). Esu, Edet, Teme, \& Okereke (1994) reported a widespread of carbonate rocks occurrence in Nigeria.

Carbonate rocks have several industrial and engineering applications. Limestone is used as raw materials in construction industries for cement production, road aggre- gates, floor tiles, etc. Marble is also use as decorative aggregates such as building stone, floor tiles, tombstones, sculpture etc. For all these applications the physical and mechanical properties of the rocks are fundamental. Prevailing environmental conditions such as temperature, pressure, humidity etc. are significant factors that could affect the properties of the rocks and consequently affect the suitability of their applications.

Elevated temperature has been recognised to have a substantial effect on the properties of carbonate rocks (Yavuz, Demirdag, \& Caran, 2010; Shafiei \& Dusseault, 2012; González-Gómez et al., 2015). When engineering structures

(C) 2018. M.A. Idris. Published by the Dnipro University of Technology on behalf of Mining of Mineral Deposits.

This is an Open Access article distributed under the terms of the Creative Commons Attribution License (http://creativecommons.org/licenses/by/4.0/),

which permits unrestricted reuse, distribution, and reproduction in any medium, provided the original work is properly cited. 
made of carbonate rocks are exposed to an elevated temperature such as during fire outbreaks, the strength of the structures is affected and this poses a severe danger to people and properties in and around the structures. Prolonged thermal induced changes in limestone region could also affect the ecosystem as the changes in the properties of the limestone most especially porosity and permeability could induced more water infiltration and consequently erosion within the region (González-Gómez et al., 2015). Therefore, it is essential to study how the properties of rock will be affected due to any possible increase in temperature.

Many researchers have studied the effects of high temperature on the physical and mechanical properties of different types of rocks either granitic, carbonate rocks or sandstones. Heuze (1983) reported irreversible changes in the properties of granitic rocks when subjected to high temperature - the changes which include, among others, change in colour, reduction in strength or disintegration of the rock fabrics. Nasseri, Schubnel, \& Young (2007) conducted an experimental study of some physico-mechanical characteristics of Westerly granite at high temperature and found a noticeable increase in the number and average opening distance of micro-cracks of the rock at a temperature above $250^{\circ} \mathrm{C}$. Ferrero \& Marini (2001) reported the extension of primary micro-cracks and developments of new cracks when calcite marbles were subjected to thermal treatment. Other researchers have reported similar results on the effects of elevated temperatures on the development and propagation of rocks' micro-cracks thereby reducing the strength of the rock (e.g. Cantisani et al., 2009; Ferrero, Migliazza, Spagnoli, \& Zucali, 2014; Berger, Ebert, Ramseyer, Gnos, \& Decrouez, 2016; Peng, Rong, Cai, Yao, \& Zhou, 2016; Sirdesai, Singh, Ranjith, \& Singh, 2017).

The physical and mechanical properties of carbonate rocks, as well as other rocks, determines their suitability for engineering applications and these properties change when subjected to high temperature. Brotóns, Tomás, Ivorra, \& Alarcón (2013) examined the effect of high temperatures on the physical and mechanical properties of calcarenite rock samples. They observed that Young's modulus, Poisson's ratio and uniaxial compressive strength of the rock decrease as the temperature increases up to $600^{\circ} \mathrm{C}$. Similar results were also reported by Yavuz, Demirdag, \& Caran (2010) and González-Gómez et al. (2015) for carbonate rocks.

In this study, carbonate rocks (i.e. limestone and marbles) in some part of Nigeria were selected for the investigation because of their increased engineering and construction applications. Some of these applications such as floor and wall tiles, sculptures, tombs etc. could be subjected to elevated temperature in case of fire outbreak. Most of the available studies on Nigerian carbonate rocks such as Anifowose (1984) and Esu, Edet, Teme, \& Okereke (1994) are on the estimation of the physical and mechanical properties of the rocks without considering the changes on these properties when the rocks are subjected to high temperatures.

Therefore, this study aims to investigate the effects of the elevated temperatures on the physical and mechanical properties of some of the Nigerian carbonate rocks. Block samples of the rocks were prepared and subjected to different temperatures up to $900^{\circ} \mathrm{C}$. The density, porosity, and uniaxial compressive stress of the samples were determined before the thermal treatment and after the treatment. The results were analysed to determine the significance of the elevated temperatures on the rock.

\section{MATERIAL AND METHODS}

\subsection{Description of the rock samples}

The carbonate rocks used for this investigation are limestone and marble. The limestone samples were collected from the quarry of BUA Cement Company in Okpella while the marble samples were selected from Geoworks quarry in Igarra. The two quarries were located in Edo state, South-southern Nigeria. The geochemical analyses of the Okpella deposits show that the deposits contain mostly calcite with the average content of $96 \mathrm{wt} \%$ (Onimisi et al., 2012; Aghamelu \& Amah, 2017). Obasi (2012) also reported that the Igarra marble is calcitic with low dolomite content - the average calcite content is about $90 \mathrm{wt} \%$ while that of dolomite is about $7 \mathrm{wt} \%$.

The carbonate rocks of these regions were selected for this study because of their high compositional features and economic values (Obasi, 2012; Aina, 2014; Akinniyi \& Ola, 2016). Though these samples were collected from the blasted rock at the quarries, only the intact rock samples free of any blast induced fractures were selected. Sample preparations for the determination of the physical and mechanical properties were conducted in the Rock mechanics laboratory at the Federal University of Technology Akure, Nigeria. The preparation of these samples, test procedures and calculations followed the relevant standards as suggested by International Society of Rock Mechanics (ISRM) (Ulusay \& Hudson, 2007). The limestone and marble samples were cut into cuboid shapes of dimension $100 \mathrm{~mm}$ in length, $50 \mathrm{~mm}$ in width and $50 \mathrm{~mm}$ in breadth using the masonry saw cutter that utilized water and soluble oil as its coolant to reduce the rate of the dust that was being generated during cutting of the samples. Since the samples were wet after cutting, the samples were allowed to dry before they were used for the study. Twenty limestone samples of the cuboid shape were made and divided into ten pairs. Similarly, twenty cuboid shape marble samples were made and divided into ten pairs.

\subsection{Heat treatment}

The rate at which a rock sample is heated in a furnace will determines the extent of changes in the physical and mechanical properties of the rock sample. The high rate of heating can cause the rock sample to fail earlier due to sudden thermal shock. For the rock to be heated evenly, it is imperative to have a slow rate of heating (Yavuz, Demirdag, \& Caran, 2010). To avoid the thermal shock, the rock samples for this investigation were subjected to heat treatment at a rate of $5^{\circ} \mathrm{C} / \mathrm{min}$ in a carbolite muffle furnace. After the samples were heated to the targeted temperature, the temperature was kept constant for two hours. After that, the samples were allowed to cool a little in the furnace before they were completely cooled in the desiccator to ensure that the samples were not allowed to be disrupted by atmospheric temperature.

Based on the maximum temperature they were subjected to, the limestone and marble samples were categorized into ten groups: 100, 200, 300, 400, 500, 600, 700, 
$800,900^{\circ} \mathrm{C}$ and ambient temperature. The ambient temperature during the experiment was approximately $25^{\circ} \mathrm{C}$. Each group contains two specimens - one specimen for mechanical properties tests while the other for physical properties tests.

\subsection{Determination of the physical and mechanical properties}

The porosity and dry density were determined to study the effect of the elevated temperature on the physical properties of the carbonates rocks while the uniaxial compressive strength (UCS) was determined to assess the impact of the temperature on the mechanical property. The porosity and dry density are essential properties of any rock, and they are highly correlated. The porosity influence the internal surface area per unit material volume and hence determines the transport properties and strength of any rock materials (Yavuz, Demirdag, \& Caran, 2010). According to Martin, Noel, Boyd, \& Price (1996), a compressive study of porosity can provide information on the susceptibility of any rock type to thermal stress. The uniaxial compressive strength (UCS) of intact rock samples is one of the most important mechanical properties of rock required for the design of any geotechnical, structural and mining engineering projects. Therefore, the three properties selected could give a better representation of the physical and mechanical behaviour of the carbonate rocks when subjected to elevated temperature.

The porosity and dry density of the rock samples were determined using the saturation and buoyancy method as suggested by ISRM (Brown, 1981). The technique, however, can only be applied to rocks which exhibit intact and non-swelling characteristics. Since the limestone and the marble are intact and do not swell in the presence of water, this technique was employed to measure their porosity. The saturated mass $\left(M_{s a t}\right)$, the submerged-saturated mass $\left(M_{s u b}\right)$, and the oven-dry mass $\left(M_{s}\right)$ of the samples were measured using the procedure suggested by ISRM (Brown, 1981). The bulk volume $(V)$ of the samples was calculated by dividing the difference between $M_{\text {sat }}$ and $M_{s u b}$ with the density of water $\left(\rho_{w}\right)$ as shown Equation (1). The porosity $(\eta)$ and the dry density $\left(\rho_{d}\right)$ of the samples was calculated using Equations (2) and (3), respectively:

$$
V=\frac{M_{s a t}-M_{s u b}}{\rho_{w}} ;
$$

$\eta=\frac{M_{\text {sat }}-M_{s}}{M_{\text {sat }}-M_{\text {sub }}} \cdot 100$

$\eta=\frac{M_{s}}{V}$

The uniaxial compressive strength (UCS) of the samples was estimated using Point Load Test (PLT) following the method suggested for determine point load strength by ISRM (Brown, 1981). Though UCS is best determined using UCS machine following the procedure outlined by ISRM (Brown, 1981) however, it is timeconsuming and expensive when compared with indirect estimation of the UCS using point load tests.

The block samples of the carbonate rocks of dimension $100 \times 50 \times 50 \mathrm{~mm}$ were loaded diametrically during the test.
The load is increased steadily until the failure of the samples occurred and the load $(P)$ was recorded. Figure 1 shows some of the samples after the point load index testthe failure mode of the samples is the typical mode of failure for valid block tests as described by ISRM (Brown, 1981). The point load strength index $\left(I_{S}\right)$ of the samples was calculated using Equation (4):

$I_{s}=\frac{P}{D_{e}^{2}}$,

where:

$D_{e}$ - the equivalent core diameter which is given by $D_{e}=\sqrt{\frac{4 A}{\pi}}$;

$A$ - the minimum cross-sectional area of the plane through the platen contact point.

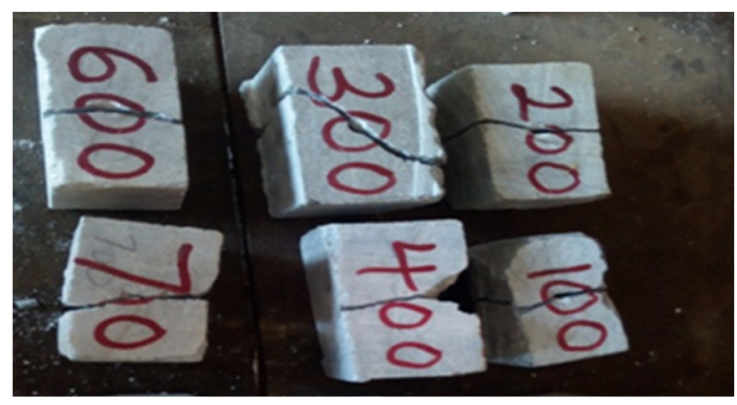

Figure 1. Some rock samples after point load index tests

Since the tested samples were in block form, it varied as a function of $D_{e}$. Therefore, a size correction was applied as suggested by ISRM (Brown, 1981) to take care of the equivalent diameters for the samples other than the standardised $50 \mathrm{~mm}$ in diameter. Therefore, the size-corrected point load strength index $\left(I_{s(50)}\right)$ of the samples was calculated using Equation (5):

$I_{s(50)}=\left(\frac{D_{e}}{50}\right)^{0.45} \cdot I_{s}$.

The major challenge of using the point load test index for the estimation of the uniaxial compressive strength of rock samples is the determination of the appropriate correlation between $\left(I_{s(50)}\right)$ and UCS. Many researchers have proposed a number of the correlations based on the tests they performed on different rock types. Some of them are Broch \& Franklin (1972); Bieniawski (1975); Akram \& Bakar (2007); Kim, Kim, Kang, Kang, \& Baek (2012); Salah, Omar, \& Shanableh (2014); Elhakim (2015). However, estimation of the UCS using these correlations for different rock types could lead to large variability and errors. Therefore, it is highly recommended to develop $\mathrm{UCS}-I_{s(50)}$ correlations to be used for any specific rock type and local geologies (Elhakim, 2015).

Therefore, based on the information from the quarries and the UCS data on the Igarra marble reported by Saliu, Akindoyeni, \& Okewale (2013), linear regression models with zero intercept which correlate the UCS and $I_{S(50)}$ were developed. The coefficients of the linear equations for the limestone and marble were estimated to be 10.3 and 11.8 , respectively. 


\section{RESULTS AND DISCUSSION}

\subsection{Variation of the sample porosity with increased temperature}

The porosity of an intact rock depends on the number and width of the pores and the pre-existing cracks in the rock hence any changes in the characteristics of the pores and the cracks due to external factors will affect the porosity of the rock. Elevated temperature is one of such factors. Generally, the porosity of the limestone and marble samples when subjected to high temperature shows a gradual increase when compared with the porosity of the samples at ambient temperature as shown in Figures 2 and 3 , respectively.

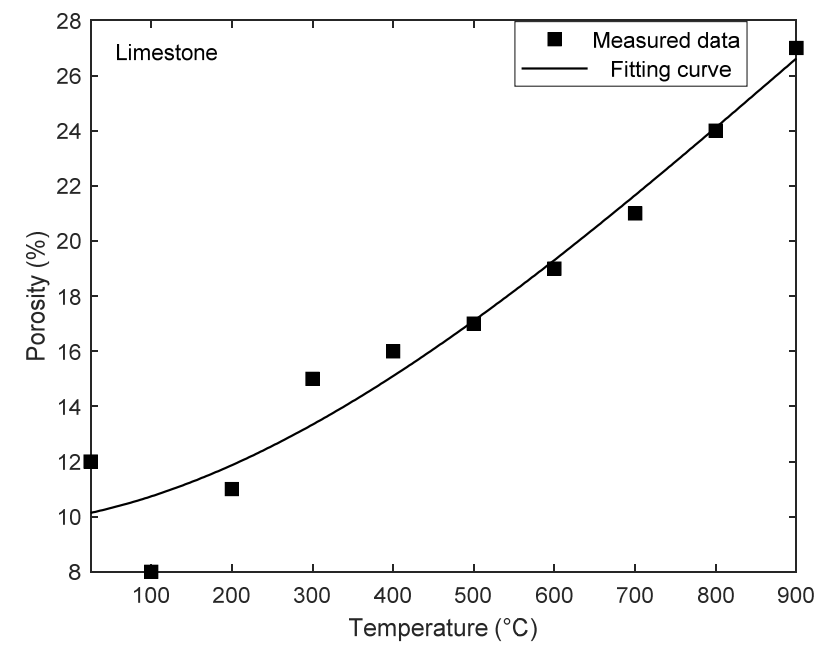

Figure 2. Variation of porosity of the limestone samples with different temperatures

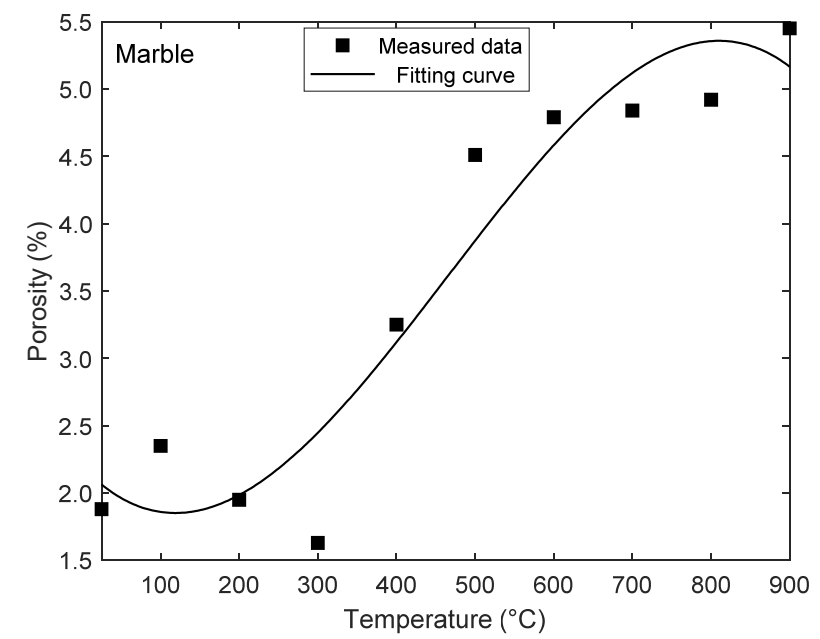

Figure 3. Variation of porosity of the marble samples with different temperatures

However, at some specific temperature range, there is a decrease in the porosity of the samples. The Igarra marble is less porous when compared with the limestone sample however, the effect of the temperature is more significant on its porosity than that of the limestone. The porosity of the marble samples increased by $189 \%$ at a temperature of $900^{\circ} \mathrm{C}$ when compared with its porosity at the ambient temperature while that of the limestone sample increased by $125 \%$. As shown in Figure 3, the porosity of the marble increased at the temperature of $100^{\circ} \mathrm{C}$. The sudden increase in the porosity may be due to the evaporation of some locked-in free water in the pre-existing pores of the samples thereby exposing the pores. The decrease in the porosity of the limestone and the marble samples at a temperature of 100 and $300^{\circ} \mathrm{C}$, respectively as shown in Figures 2 and 3 is a possible indication of the expansion of the rocks grains and the consequent closure of the pores and pre-existing fissures in the samples. When a rock is subjected to high temperature it leads to the expansion of the grains that constitute the mineral assemblage of the rock hence the closure of the pre-existing pores leading to the compaction of the rock sample (Sirdesai, Singh, Ranjith, \& Singh, 2017). Further increase in the temperature will lead to more expansion. Since each mineral grain has different thermal expansion coefficient at a certain temperature, the contrast in the thermal expansion will induced new micro-cracks and thereby increase the porosity of the rock samples (Sirdesai, Singh, Ranjith, \& Singh, 2017). The porosity of the limestone and marble samples steadily increased within the range $300-900^{\circ} \mathrm{C}$ and $400-900^{\circ} \mathrm{C}$, respectively and this is a possible indication of the creation of new micro-fractures at the onset of the respective temperature ranges. By regression analysis, the relationship between the porosity of the limestone $\left(\eta_{L}\right)$ and the marble $\left(\eta_{M}\right)$ with the heating temperature $(T)$ can be expressed with Equations (6) and (7), respectively. The coefficient of correlation $\left(R^{2}\right)$ for the equations (6) and (7) are 0.95 and 0.91 , respectively:

$$
\begin{aligned}
& \eta_{L}=-8\left(\frac{T}{1000}\right)^{3}+0.2\left(\frac{T}{100}\right)^{2}+\frac{5 T}{1000}+10 ; \\
& \eta_{M}=-20\left(\frac{T}{1000}\right)^{3}+0.3\left(\frac{T}{100}\right)^{2}-\frac{6 T}{1000}+2.2 .
\end{aligned}
$$

\subsection{Variation of the sample density with elevated temperature}

Density is one of the physical properties of rock which determines its application for engineering purposes. The effect of the high temperature on the densities of the limestone and marble samples is shown in Figures 4 and 5. The density of the samples decrease with increase in temperature when compared with their densities at the ambient temperature however, the changes are not as significant as that of their porosities. As shown in Figure 4 the temperature effect on the limestone density is more significant than that of the marble sample which is expected because the marble sample is less porous than the limestone sample as shown in Figure 3. The density of the limestone decrease by $41 \%$ at the temperature of $900^{\circ} \mathrm{C}$ when compared with its density at the ambient temperature while the density of the marble decrease by $15 \%$ at the same temperature range.

A remarkable reduction in the density of the samples, when compared with their initial densities at ambient temperature, was observed at the temperature above $200^{\circ} \mathrm{C}$ and $300^{\circ} \mathrm{C}$ for the limestone and marble samples, respectively. This observation is also an indication that at these temperatures there is possibility of the creation of new micro-cracks and pores, as explained in Section 3.1, which leads to the increase in their porosities. 


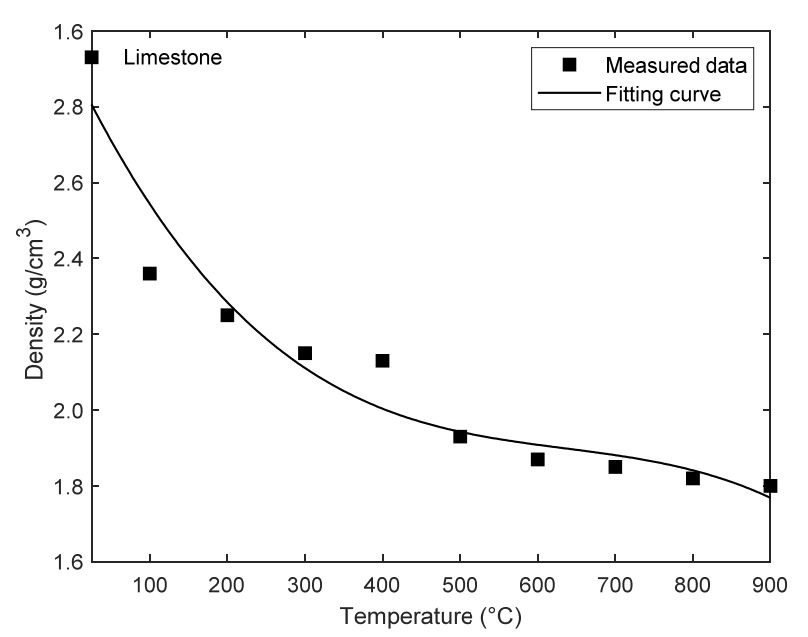

Figure 4. Variation of density of the limestone samples with different temperatures

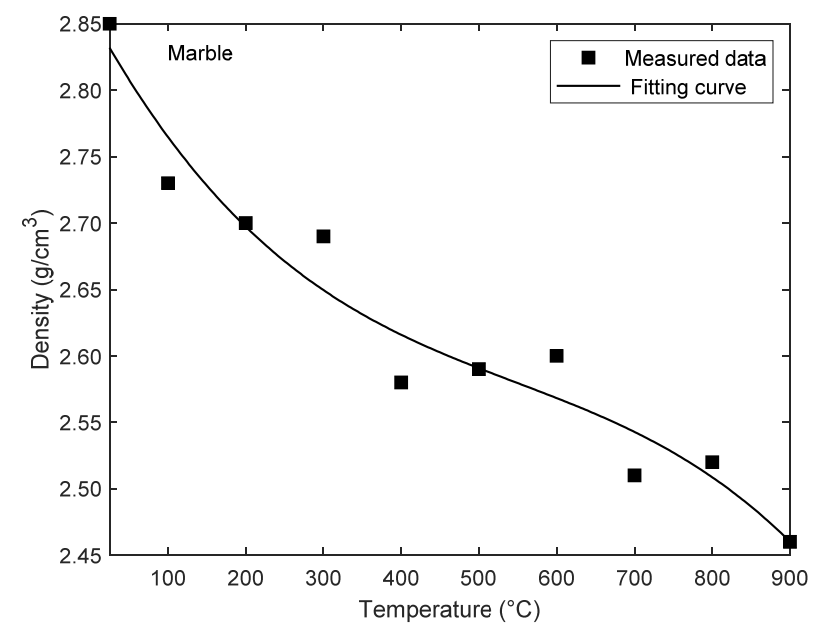

Figure 5. Variation of density of the marble samples with different temperatures

The increase in the porosity makes the samples less compact and consequently reduced their densities. Porosity and dry density are highly correlated - a highly porous rock usually has low density (Brown, 1981). By regression analysis, the fitting Equations (8) and (9) describe the relationship between the density of the limestone $\left(\rho_{L}\right)$ and the marble $\left(\rho_{M}\right)$ with the temperature $(T)$, respectively. The coefficient of correlation $\left(R^{2}\right)$ for both equations are 0.95 :

$$
\begin{aligned}
& \rho_{L}=-3\left(\frac{T}{1000}\right)^{3}+6\left(\frac{T}{1000}\right)^{2}-\frac{4 T}{1000}+2.7 \\
& \rho_{M}=-\left(\frac{T}{1000}\right)^{3}+2\left(\frac{T}{1000}\right)^{2}-\frac{T}{1000}+2.9
\end{aligned}
$$

\subsection{Temperature effect on the uniaxial compressive strength (UCS)}

The UCS is one of the most important mechanical properties of rock as it is often used as a key input for the characterisation of the rock material strength. It also determines rock suitability for engineering purposes hence any changes in the UCS of rock due to external factors such as high temperature will affect the engineering application of the rock.

The results of the effect of the elevated temperature on the limestone and marble samples are presented in Figures 6 and 7 . The results reveal the trend that the increased temperature has a significant effect on the strength of both limestone and marble samples. The overall impact of the elevated temperature is almost the same on both rock samples when considering the percentage decrease in their strength at $900^{\circ} \mathrm{C}$. However, there are differences in the pattern of change in the strength of the rocks at different temperatures.

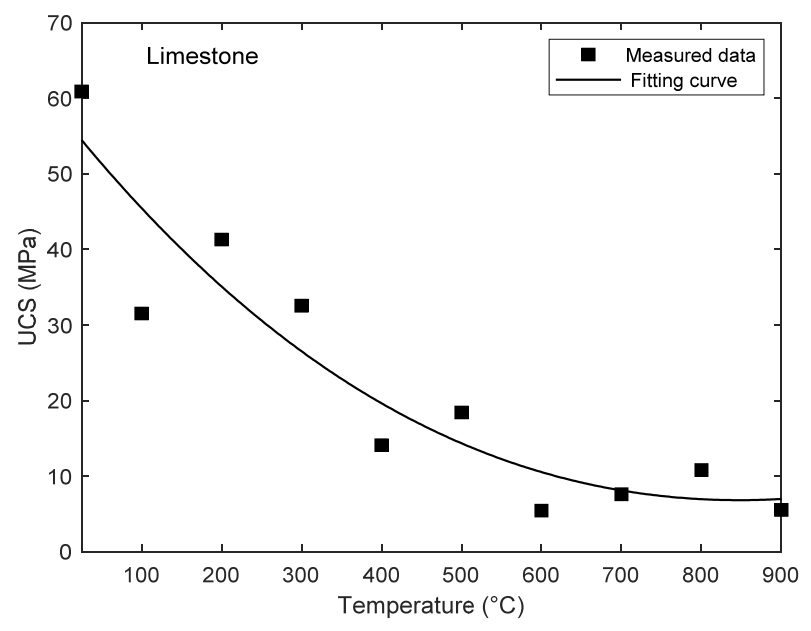

Figure 6. Variation of UCS of the limestone samples with different temperatures

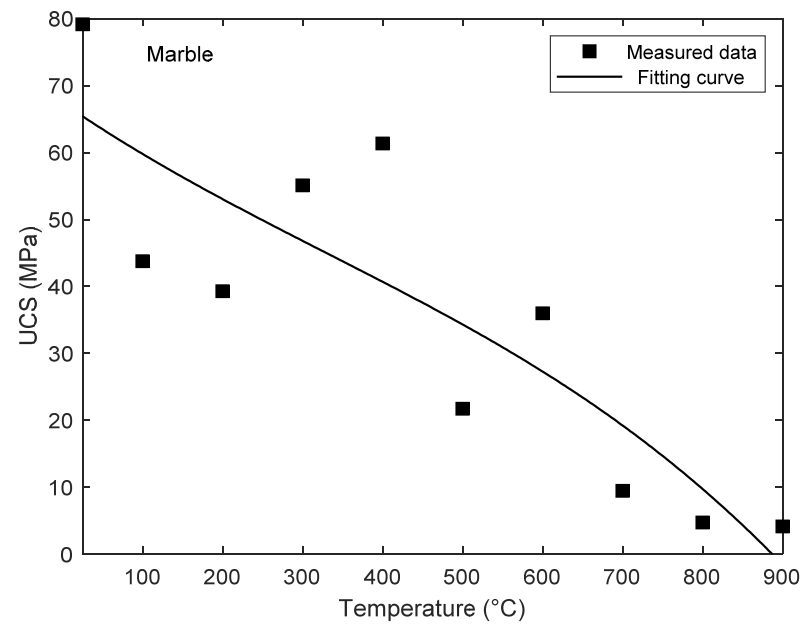

Figure 7. Variation of UCS of the marble samples with different temperatures

As shown in Figure 7 the UCS of the marble generally decreased with increased temperature but with an intermittent increase in its strength at a specific heating temperature. For instance, the UCS at $400^{\circ} \mathrm{C}$ is about $30 \%$ higher than that at $300^{\circ} \mathrm{C}$ and the UCS also increased by $55 \%$ from 400 to $500^{\circ} \mathrm{C}$. Notwithstanding the intermittent increase, the strength of the limestone decreased rapidly from 60 to $4 \mathrm{MPa}$, a decrease of about $93 \%$ from 400 to $900^{\circ} \mathrm{C}$. This temperature range (i.e. above $400^{\circ} \mathrm{C}$ ) falls within the range when the porosity of the marble rapidly 
increased as explained previously. An increased in the porosity makes the rock sample less compact and consequently result to the reduction of the rock strength. These observations are similar to those reported by Zhu, Tian, Jiang, \& Cheng (2018) for Chinese marbles. They observed that at a temperature above $200^{\circ} \mathrm{C}$ the trend of the strength of some marble with temperature can either increasing or decreasing while most marble basically decrease with temperature from 200 to $800^{\circ} \mathrm{C}$. For the limestone, decreasing trend of the strength with increase in temperature was observed as shown in Figure 6.

Similar to the behaviour of the marble sample, the trend of the UCS with temperature also show some intermittent increase. From 100 to $200^{\circ} \mathrm{C}$ the strength increased by $30 \%$. From 400 to $500^{\circ} \mathrm{C}$ the strength also increased by $30 \%$. The UCS at $700^{\circ} \mathrm{C}$ is about $40 \%$ higher than that at $600^{\circ} \mathrm{C}$ and also the strength increased by $40 \%$ from 700 to $800^{\circ} \mathrm{C}$. Nevertheless, the strength of the limestone decreased rapidly from 41 to $5.6 \mathrm{MPa}$, a decrease of about $86 \%$ from 200 to $900^{\circ} \mathrm{C}$. González-Gómez et al. (2015) has also reported similar behaviour for some Mexican limestone when subjected to high temperature. By using regression analysis, equations (10) and (11) were found to provide a good fit to changes in the UCS of the lime stone $\left(\mathrm{UCS}_{L}\right)$ and the marble $\left(\mathrm{UCS}_{M}\right)$, respectively as a function of the heating temperature $(T)$. The coefficient of correlation $\left(R^{2}\right)$ for the equations (10) and (11) are 0.88 and 0.75 , respectively:

$$
\begin{aligned}
& U C S_{L}=-20\left(\frac{T}{1000}\right)^{3}+\left(\frac{T}{100}\right)^{2}-\frac{13 T}{100}+58 \\
& U C S_{M}=-60\left(\frac{T}{1000}\right)^{3}+0.6\left(\frac{T}{100}\right)^{2}-\frac{8 T}{100}+67 .
\end{aligned}
$$

\section{CONCLUSIONS}

Limestone and marble are significant rocks in Nigeria because of their increasing structural and engineering applications. Many researchers have investigated the properties, compositional features and economic values of the carbonate rock. However, the effects of the prevailing environmental conditions such as high temperature on the Nigerian carbonate rocks have not been much reported. The knowledge of these effects is essential to determine the behaviour of any structures made of these rocks when exposed to high temperature. In this study, the effects of the elevated temperature on the physical and mechanical properties of the carbonate rocks were investigated. Dry density, porosity and UCS of the rock when subjected to a different high temperature. The effects of the high temperature on the physical and mechanical properties of the rocks were analysed, and from the results, the following conclusions can be drawn:

1. Generally, the elevated temperature has a significant effect on the physical and mechanical properties of the carbonate rocks.

2. The measured porosity for the limestone and marble increased steadily with the increased temperature at a temperature above 300 and $400^{\circ} \mathrm{C}$, respectively. However, the increase is more remarkable for the marble than the limestone, though the marble is less porous than limestone. A sudden increase in the porosity of the marble was observed at a temperature of $100^{\circ} \mathrm{C}$, which could be due to the evaporation of locked-in free water in the pre-existing pores. Additional studies would be required to confirm this assumption.

3. The density of the rocks showed a decreasing trend with the increased temperature, but the changes are not as significant as that of the porosity. A remarkable reduction in the density of limestone and marble was observed at the temperature of 200 and $300^{\circ} \mathrm{C}$, respectively.

4. The UCS of the limestone and marble behaved differently, though the general decreasing trend was observed. The UCS of the marble increased intermittently between the temperature range of 300 and $500^{\circ} \mathrm{C}$ and later decreased rapidly from the temperature above $400^{\circ} \mathrm{C}$. The rapid reduction in the UCS of the limestone occurred at a temperature above $200^{\circ} \mathrm{C}$, though an increased in its UCS was observed at a temperature range of 100 and $200^{\circ} \mathrm{C}$.

5. From the previous studies, such as Sirdesai, Singh, Ranjith, \& Singh (2017), it has been observed that at a specific temperature, new micro-cracks and pores are created in rock samples due to thermal stress. The new cracks and pores lead to the increase in the porosity and reduction in the density and consequently reduce the strength of the rock material. Therefore, in this study, the possible onsets of the progressive development of these new cracks and pores for the limestone and marble are at a temperature above 300 and $400^{\circ} \mathrm{C}$, respectively.

\section{ACKNOWLEDGEMENTS}

The author wish to express his appreciation to Mr. J.O. Ayeni, Mr. M.B. Jamiu, Mr. I.O. Olanrewaju and Mr. T.V. Oluwafemi for their contribution in acquiring the data used for this study.

\section{REFERENCES}

Aghamelu, O.P., \& Amah, J.I. (2017). Quality and durability of some marble deposits in the southern schist belt (Nigeria) as construction stones. Bulletin of Engineering Geology and the Environment, 76(4), 1563-1575. https://doi.org/10.1007/s10064-016-0939-6

Aina, A.E. (2014). Compositional features and economic appraisal of limestone deposit in Ososo, Edo State, SouthWestern Nigeria. Unpublished M.Sc. Thesis. Ibadan, Nigeria: University of Ibadan.

Akinniyi, A.A., \& Ola, S.A. (2016). Investigation of certain engineering properties of some Nigerian limestone deposits for cement production. Electronic Journal of Geotechnical Engineering, (21), 10471-10482.

Akram, M., \& Bakar, M.A. (2007). Correlation between uniaxial compressive strength and point load index for salt-range rocks. Pakistan Journal of Engineering and Applied Sciences, (1), 1-7.

Anifowose, Y.B. (1984). An estimation of indirect tensile and compressive strength of Ewekoro Limestone, S.W. Nigeria. Unpublished M.Sc. Thesis. Ibadan, Nigeria: University of Ibadan.

Berger, A., Ebert, A., Ramseyer, K., Gnos, E., \& Decrouez, D. (2016). Dolomite microstructures between $390^{\circ}$ and $700^{\circ} \mathrm{C}$ : Indications for deformation mechanisms and grain size evolution. Journal of Structural Geology, (89), 144-152. https://doi.org/10.1016/i.jsg.2016.06.001

Bieniawski, Z.T. (1975). The point-load test in geotechnical practice. Engineering Geology, 9(1), 1-11. https://doi.org/10.1016/0013-7952(75)90024-1 
Broch, E., \& Franklin, J.A. (1972). The point-load strength test. International Journal of Rock Mechanics and Mining Sciences \& Geomechanics Abstracts, 9(6), 669-676. https://doi.org/10.1016/0148-9062(72)90030-7

Brotóns, V., Tomás, R., Ivorra, S., \& Alarcón, J.C. (2013). Temperature influence on the physical and mechanical properties of a porous rock: San Julian's calcarenite. Engineering Geology, (167), 117-127. https://doi.org/10.1016/j.enggeo.2013.10.012

Brown, E.T. (1981). Rock characterization testing and monitoring: ISRM suggested methods. Oxford: Pergamon Press.

Cantisani, E., Pecchioni, E., Fratini, F., Garzonio, C.A., Malesani, P, \& Molli, G. (2009). Thermal stress in the Apuan marbles: Relationship between microstructure and petrophysical characteristics. International Journal of Rock Mechanics and Mining Sciences, 46(1), 128-137. https://doi.org/10.1016/j.ijrmms.2008.06.005

Elhakim, A.F. (2015). The use of point load test for Dubai weak calcareous sandstones. Journal of Rock Mechanics and Geotechnical Engineering, 7(4), 452-457. https://doi.org/10.1016/j.jrmge.2015.06.003

Esu, E.O., Edet, A.E., Teme, S.C., \& Okereke, C.S. (1994). A study of some Nigerian carbonate rocks for the building construction industry. Engineering Geology, 37(3-4), 271-283. https://doi.org/10.1016/0013-7952(94)90061-2

Ferrero, A.M., \& Marini, P. (2001). Experimental studies on the mechanical behaviour of two thermal cracked marbles. Rock Mechanics and Rock Engineering, 34(1), 57-66. https://doi.org/10.1007/s006030170026

Ferrero, A.M., Migliazza, M., Spagnoli, A., \& Zucali, M. (2014). Micromechanics of intergranular cracking due to anisotropic thermal expansion in calcite marbles. Engineering Fracture Mechanics, (130), 42-52.

https://doi.org/10.1016/j.engfracmech.2014.01.004

González-Gómez, W.S., Quintana, P., May-Pat, A., Avilés, F., May-Crespo, J., \& Alvarado-Gil, J.J. (2015). Thermal effects on the physical properties of limestones from the $\mathrm{Yu}$ catan Peninsula. International Journal of Rock Mechanics and Mining Sciences, (75), 182-189. https://doi.org/10.1016/j.ijrmms.2014.12.010

Heuze, F.E. (1983). High-temperature mechanical, physical and Thermal properties of granitic rocks - A review. International Journal of Rock Mechanics and Mining Sciences \& Geomechanics Abstracts, 20(1), 3-10. https://doi.org/10.1016/0148-9062(83)91609-1

Kim, G.M., Kim, D.H., Kang, J.S., Kang, S.S., \& Baek, H. (2012). A study on the correlation between uniaxial compressive strength and point load strength index of lime-stone of Imgye area. Journal of Korean Society for Rock Mechanics, 22(5), 330-338.

https://doi.org/10.7474/tus.2012.22.5.330
Martin, R.J., Noel, J.S., Boyd, P.J., \& Price, R.H. (1996). Thermal expansion as a function of confining pressure for welded tuff from Yucca Mountain. In Proceedings of the $2^{\text {nd }}$ North American Rock Mechanics Symposium (pp. 1-8). Montreal, Quebec, Canada: American Rock Mechanics Association.

Nasseri, M.H.B., Schubnel, A., \& Young, R.P. (2007). Coupled evolutions of fracture toughness and elastic wave velocities at high crack density in thermally treated Westerly granite. International Journal of Rock Mechanics and Mining Sciences, 44(4), 601-616.

https://doi.org/10.1016/j.ijrmms.2006.09.008

Obasi, R.A. (2012). Geochemistry and appraisal of the economic potentials of Calc-gneiss and marble from Igarra, Edo State, Southwest Nigeria. ARPN Journal of Science and Techno$\log y,(2), 1018-1021$.

Peng, J., Rong, G., Cai, M., Yao, M.-D., \& Zhou, C.-B. (2016). Physical and mechanical behaviors of a thermal-damaged coarse marble under uniaxial compression. Engineering Geology, (200), 88-93. https://doi.org/10.1016/j.enggeo.2015.12.011

Salah, H., Omar, M., \& Shanableh, A. (2014). Estimating unconfined compressive strength of sedimentary rocks in United Arab Emirates from point load strength index. Journal of Applied Mathematics and Physics, 02(06), 296-303. https://doi.org/10.4236/jamp.2014.26035

Saliu, M.A., Akindoyeni, A.F., \& Okewale, I.A. (2013). Correlation between blast efficiency and uniaxial compressive strength. International Journal of Engineering and Techno$\log y,(3), 799-805$.

Shafiei, A., \& Dusseault, M.B. (2012). Viscous oil carbonates at elevated temperature. In Proceedings of the $46^{\text {th }}$ US Rock Mechanics/Geomechanics Symposium (pp. 1-12). Chicago, Illinois, United States: American Rock Mechanics Association.

Sirdesai, N.N., Singh, T.N., Ranjith, P.G., \& Singh, R. (2017). Effect of varied durations of thermal treatment on the tensile strength of red sandstone. Rock Mechanics and Rock Engineering, 50(1), 205-213. https://doi.org/10.1007/s00603-016-1047-4

Ulusay, R., \& Hudson, J.A. (2007). The complete ISRM suggested methods for rock characterization, testing and monitoring: 1974-2006. Ankara, Turkey: International Society for Rock Mechanics (ISRM) Turkish National Group.

Yavuz, H., Demirdag, S., \& Caran, S. (2010). Thermal effect on the physical properties of carbonate rocks. International Journal of Rock Mechanics and Mining Sciences, 47(1), 94-103. https://doi.org/10.1016/j.ijrmms.2009.09.014

Zhu, Z., Tian, H., Jiang, G., \& Cheng, W. (2018). Effects of high temperature on the mechanical properties of Chinese marble. Rock Mechanics and Rock Engineering, 51(6), 1937-1942. https://doi.org/10.1007/s00603-018-1426-0

\title{
ВПЛИВ ВИСОКИХ ТЕМПЕРАТУР НА ФІЗИКО-МЕХАНІЧНІ ВЛАСТИВОСТІ КАРБОНАТНИХ ПОРІД У ПІВДЕННОЇ НІГЕРІЇ
}

\author{
М.А. Ідріс
}

Мета. Вивчення впливу високих температур на фізико-механічні властивості карбонатних порід на основі експериментальних термічних досліджень їх зразків для проектування будівель і споруд, стійких до руйнувань від пожеж.

Методика. Кубічні зразки порід нагрівалися в печі до $900^{\circ} \mathrm{C}$ з інтервалом у $100^{\circ} \mathrm{C}$, а потім охолоджувалися до кімнатної температури. Пористість, об’ємна маса в сухому стані, міцність на одноосьовий стиск (МОС) зразків визначалися при різних високих температурах. Пористість та об’ємна маса в сухому стані вимірювалися шляхом визначення насичення й плавучості зразків, у той час як МОС оцінювалася при випробуванні зразків на зосереджене навантаження.

Результати. Результати дослідження свідчать про те, що високі температури чинять суттєвий вплив на фізикомеханічні властивості карбонатних порід. 3 підвищенням температури пористість порід має стійку тенденцію до збільшення, а об'ємна маса - до зменшення, особливо при температурах вище $300^{\circ} \mathrm{C}$. МОС також в цілому знижується при підвищенні температури, однак при деяких температурах спостерігається тимчасове збільшення міцності. 
Наукова новизна. Вперше для карбонатних порід Нігерії встановлено характер впливу високих температур на їх фізико-механічні властивості, що раніше не досліджувалось. Дане дослідження проведено 3 метою заповнення прогалини у вивченні цього питання.

Практична значимість. Розширено уявлення щодо впливу високих температур на карбонатні породи та визначено критичні значення температури, при яких їх властивості зазнають суттєвих і незворотніх змін. Ці дані $є$ досить важливими для відновлення значущих споруд із карбонатних порід, які піддалися руйнуванню під час пожежі.

Ключові слова: вапняк, мармур, висока температура, властивості породи, тепловий вплив

\section{ВЛИЯНИЕ ВЫСОКИХ ТЕМПЕРАТУР НА ФИЗИКО-МЕХАНИЧЕСКИЕ СВОЙСТВА КАРБОНАТНЫХ ПОРОД В ЮЖНОЙ НИГЕРИИ}

\section{М.А. Идрис}

Цель. Изучение влияния высоких температур на физико-механические свойства карбонатных пород на основе экспериментальных термических исследований их образцов для проектирования зданий и сооружений, устойчивых к разрушениям от пожаров.

Методика. Кубические образцы пород нагревались в печи до $900^{\circ} \mathrm{C}$ с интервалом в $100^{\circ} \mathrm{C}$, а затем охлаждались до комнатной температуры. Пористость, объемная масса в сухом состоянии, прочность на одноосное сжатие (ПОС) образцов определялись при различных высоких температурах. Пористость и объемная масса в сухом состоянии измерялись путем определения насыщения и плавучести образцов, в то время как ПОС оценивалась при испытании образцов на сосредоточенную нагрузку.

Результаты. Результаты исследования свидетельствуют о том, что высокие температуры оказывают значительное влияние на физико-механические свойства карбонатных пород. С возрастанием температуры пористость пород имеет устойчивую тенденцию к увеличению, а объемная масса - к уменьшению, особенно при температуpax выше $300^{\circ} \mathrm{C}$. ПОС также в целом снижается при повышении температуры, однако при некоторых температурах наблюдается временное увеличение прочности.

Научная новизна. Впервые для карбонатных пород Нигерии установлен характер влияния высоких температур на их физико-механические свойства, что ранее не исследовалось. Данное исследование проведено для заполнения пробела в изучении этого вопроса.

Практическая значимость. Расширены представления о влиянии высоких температур на карбонатные породы и определены критические значения температуры, при которых их свойства претерпевают существенные и необратимые изменения. Эти данные очень важны для восстановления значимых сооружений из карбонатных пород, которые подверглись разрушению при пожаре.

Ключевые слова: известняк, мрамор, высокая температура, свойства породы, тепловое воздействие

\section{ARTICLE INFO}

Received: 4 June 2018

Accepted: 13 October 2018

Available online: 22 October 2018

\section{ABOUT AUTHORS}

Musa Adebayo Idris, Doctor of Philosophy, Senior Lecturer of the Department of Mining Engineering, Federal University of Technology Akure, Ilesha-Akure Expressway, P.M.B. 704, Akure, Ondo State, Nigeria. E-mail: maidris@,futa.edu.ng 